\title{
Investment Potential of Subjects of the Volga Federal District of the Russian Federation as a Factor of the Territorial Development
}

\author{
Glebova I.S. \\ Rodnyansky D.V. \\ Kazan Federal University, Institute of Management, Economics and Finance, Kazan, 420008, Russia \\ Email: drodnyansky@gmail.com
}

Doi:10.5901/mjss.2015.v6n1s3p322

\section{Abstract}

Evaluation of the investment potential of various regions of Russia is an important tool to determine the quality and effectiveness of management areas. The attractiveness of the region for investors is one of the key factors of territorial development. One of the most important tasks of the state and regional authorities is to counter the outflow of capital abroad and the creation of a favorable investment environment. The level of investment is one of the key indicators used by national authorities to assess the quality of regional governance. Integrated assessment of the investment potential of the regions of the Volga Federal District of the Russian Federation have been allocated seven subspecies potentials within each of them have been identified particular indicator.

Keywords: investment potential, regional development, territorial development, investment environment.

\section{Introduction}

The most important part of the economic policy of any country is the investment flow. A necessary condition for the development of the economy is the high investment activity. It is achieved through growth in realized investment resources and their most effective use in the priority spheres of material production and social sphere. Along with this in the literature there are different approaches to identifying the causes of the investment activity of economic agents and methods for their assessment. Some scholars as the main criterion for assessing the investment attractiveness index recovered foreign direct investment $[1,2]$, while others placed more emphasis on territorial marketing activities and regional authorities to raise funds. [3]

Holding current economic reforms in Russia testifies to the special relevance of the analysis of the problems of investment sphere and define its role in the successful implementation of the course of economic reforms needed in the Russian regions.

Over the last decade in Russia, many new approaches to the assessment of the investment potential and investment activity were designed [4]. Some scientists believe that the main indicators of the investment potential, are investments in energy infrastructure or basic capital of the largest companies in the region $[5,6,7]$. Others believe that the main characteristic of the investment attractiveness is a resource potential [8]. Several authors claims that the characteristics and components of the investment potential are different for each country and each territory $[9,10,11]$.

\section{Method}

There have been allocated eight subspecies of potentials to make an integrated assessment of the investment potential of the regions of the Volga Federal District of the Russian. Thus, production capacity was characterized GRP per capita and labor potential is defined through the average annual number of employed in the economy, life expectancy and the number of students of educational institutions of higher education per 10,000 population.

In turn, consumption potential includes the actual number of households per capita number of own cars per 1000 inhabitants and a total area of residential premises, falling by an average of 1 inhabitant. Infrastructure capacity characterized Length of railways for general use, density of public roads with hard surface $1000 \mathrm{sq} . \mathrm{km}$. territory.

Financial capacity is determined by such parameters as the regional budget surplus, tax revenues, fees and other mandatory payments to the budget of the Russian Federation, the profitability of goods sold (services). Innovation 
potential is calculated as the proportion of organizations implementing technological innovation in the total number of surveyed organizations in percent, the proportion of organizations implementing organizational innovations in the total number of surveyed organizations in percentage, the number of advanced production technology and the share of innovative products, services. The natural-resource potential was determined by the ratio of the area of the region to the area of the Russian Federation and the availability of natural reserves of mineral resources.

Thus, the total potential of the region was formed from private capacities, which, in turn, were calculated based on characterizing their performance. In order to determine the numerical value of each parameter, we used the formula $p=\frac{p_{c}}{p_{\max }} \cdot 100 \%$. After calculating the percentage of each index, the values obtained were formed and were divided by the number of indicators themselves in this particular potential, and then undertook share equal to the weight of the potential expert assessment in accordance with the formula $I=\frac{\sum_{j=1}^{n} p_{i, j}}{n_{i}} d_{i}$. It should be noted that this formula can only be used when there are assumptions about the equivalence of indicators in the calculation of particular indicator. To determine the weights of the indicators we used private data techniques "Expert RA", in which the production potential is assigned the weight - 0.7; employment - 0.7; consumer potential - 0.65; infrastructural - 0.6; Financial - 0.6; innovation potential - 0.4; natural resource -0.35

\section{Results}

We represent obtained estimates of the potential of each individual in the tables (№1-7).

Table 1. Production potential of subjects for 2007-2011, the PFD.

\begin{tabular}{|c|c|c|c|c|c|}
\hline Year & Rep. Of Bashkortostan & Rep. Od Mari El & Nizhniy Novgorod region & Samara Region & Rep. of Tatarstan \\
\hline 2007 & 51 & 27 & 49 & 63 & 70 \\
\hline 2008 & 52 & 27 & 50 & 62 & 70 \\
\hline 2009 & 48 & 30 & 49 & 54 & 70 \\
\hline 2010 & 49 & 31 & 52 & 57 & 70 \\
\hline 2011 & 49 & 29 & 49 & 54 & 70 \\
\hline
\end{tabular}

The table shows that the production potential of the Republic of Tatarstan (RT) in the time interval from 2007 to 2011, is the highest, the nearest competitor - the Samara region, since 2008, has a tendency to decrease. The lowest potential in the Republic of Mari El.

Table 2. Labor potential ofl subjects for 2007-2011, the PFD.

\begin{tabular}{|c|c|c|c|c|c|}
\hline Year & Rep. Of Bashkortostan & Rep. Od Mari El & Nizhniy Novgorod region & Samara Region & Rep. of Tatarstan \\
\hline 2007 & 62,3 & 43,6 & 65,3 & 66,3 & 69 \\
\hline 2008 & 63 & 44 & 65 & 66,3 & 69,3 \\
\hline 2009 & 63,6 & 44 & 65 & 65,33 & 69,3 \\
\hline 2010 & 63,3 & 44,6 & 64 & 64,3 & 70 \\
\hline 2011 & 63,3 & 44,3 & 63 & 63,3 & 70 \\
\hline
\end{tabular}

As for the labor potential, within 5 years of the analyzed stable leader is RT, the second is Samara region, which labor potential is characterized by instability, as since 2008 it has been a downward trend, resulting in 2011 it overtook Republic Bashkortostan and the Nizhny Novgorod region.

The results of the consumer potential are represented in table 3.

Table 3. Consumer potential of subjects for 2007-2011, the PFD.

\begin{tabular}{|c|c|c|c|c|c|}
\hline Year & Rep. Of Bashkortostan & Rep. Od Mari El & Nizhniy Novgorod region & Samara Region & Rep. of Tatarstan \\
\hline 2007 & 56 & 43 & 53 & 63,6 & 54,6 \\
\hline 2008 & 58,3 & 43,6 & 55,3 & 63,6 & 56 \\
\hline 2009 & 59 & 45,3 & 55,6 & 63,6 & 57,3 \\
\hline 2010 & 59,6 & 46,6 & 58 & 63,6 & 58,6 \\
\hline 2011 & 60,3 & 46,6 & 59,3 & 62,6 & 60,3 \\
\hline
\end{tabular}


From the data presented in Table 3, it can be noted that the most stable consumer potential for all five years has the Samara region. The Republic of Tatarstan consumption potential though is the third largest, but it is significantly inferior to the Samara region.

The next table shows infrastructure potential of regions of PFD.

Table 4. Infrastructure potential of subjects for 2007-2011, the PFD.

\begin{tabular}{|c|c|c|c|c|c|}
\hline Year & Rep. Of Bashkortostan & Rep. Od Mari El & Nizhniy Novgorod region & Samara Region & Rep. of Tatarstan \\
\hline 2007 & 48,5 & 21 & 49,5 & 57 & 48 \\
\hline 2008 & 44,5 & 19,5 & 48 & 56 & 48 \\
\hline 2009 & 47 & 19 & 49 & 52,5 & 48 \\
\hline 2010 & 45 & 17,5 & 46,5 & 49,5 & 48 \\
\hline 2011 & 45,5 & 16,5 & 46,5 & 49 & 48 \\
\hline
\end{tabular}

Based on the comprehensive data on private infrastructure capacity, the highest rates are observed in the Samara region, although, unfortunately, their values tend to decrease, the same pattern is observed in the Nizhny Novgorod region, and the Republic of Bashkortostan, and the Republic of Mari El. On their background indicators of Tatarstan Republic, despite their average level, appears to be stable. This is due primarily to the active construction of roads in preparation for the Universiade in 2013

Financial potential of the region - is the maximum possible amount of own and borrowed funds accruing region that can be used to ensure stable operation and development of the regional economy. The results are represented in table 5.

Table 5. Financial potential of subjects for 2007-2011, the PFD.

\begin{tabular}{|c|c|c|c|c|c|}
\hline Year & Rep. Of Bashkortostan & Rep. Od Mari El & Nizhniy Novgorod region & Samara Region & Rep. of Tatarstan \\
\hline 2007 & 27,9 & $-7,2$ & 41,2 & 14,7 & 30 \\
\hline 2008 & 49,7 & 6,5 & 3 & 36,1 & 40 \\
\hline 2009 & 26,2 & 5,1 & $-1,5$ & 38 & 37,2 \\
\hline 2010 & 23,4 & 4,9 & 7,3 & 35 & 17,1 \\
\hline 2011 & 35,6 & 13,3 & 17,6 & 20,3 & 17,3 \\
\hline
\end{tabular}

The table shows that the financial capacity of all study subjects - vacillates. This difference is due to the annual fluctuations in the values of the surplus (or deficit) of regional budgets. Furthermore, considering the particular indicators on financial capacity, it should be noted instability and reduced profitability of sold goods (works, services) by region, as well as the instability of income taxes and other obligatory payments to the consolidated budget of the Russian Federation.

We estimate the innovation potential of regions that characterizes how the region is free in its development from the traditional sources of economic growth. The results are shown in Table 6.

Table 6. Innovation potential of subjects for 2007-2011, the PFD.

\begin{tabular}{|c|c|c|c|c|c|}
\hline Year & Rep. Of Bashkortostan & Rep. Od Mari El & Nizhniy Novgorod region & Samara Region & Rep. of Tatarstan \\
\hline 2007 & 14,25 & 9 & 20,75 & 33,5 & 23,25 \\
\hline 2008 & 18,5 & 13,25 & 22,25 & 33,5 & 24 \\
\hline 2009 & 16,5 & 9 & 25 & 26,75 & 27 \\
\hline 2010 & 14,75 & 9,5 & 28,75 & 25,5 & 28,75 \\
\hline 2011 & 16,25 & 8,25 & 31,5 & 23,5 & 31,5 \\
\hline
\end{tabular}

Despite the high potential for innovation in 2007 in the Samara region, it has a progressive downward trend. In turn, in RT and the in the Nizhny Novgorod region there has been a gradual trend towards its increase. This can be explained by the increased share of organizations implementing technological and organizational innovation in the total number of surveyed organizations, as well as an increase in the share of innovative products, works and services in these regions of Russia.

Next analyzed potential is natural resources potential, that characterizes the region in terms of development of the traditional commodity sectors, the level and quality of production and processing of energy resources. The resulting data 
are presented in Table 7.

Table 7. Natural resources potential of subjects for 2007-2011, the PFD.

\begin{tabular}{|c|c|c|c|c|c|}
\hline Year & Rep. Of Bashkortostan & Rep. Od Mari El & Nizhniy Novgorod region & Samara Region & Rep. of Tatarstan \\
\hline 2007 & 19,5 & 3 & 27 & 8 & 13,5 \\
\hline 2008 & 19 & 3 & 27 & 8 & 12,5 \\
\hline 2009 & 19,5 & 3 & 27 & 8,5 & 15,5 \\
\hline 2010 & 20,5 & 3 & 27 & 9,5 & 18 \\
\hline 2011 & 20,5 & 3 & 27 & 9,5 & 18 \\
\hline
\end{tabular}

Table 7 shows that the maximum value of natural - resource potential belongs to the Nizhny Novgorod region, this is due to the high percentage of mining among the surveyed regions. On the second place - the Republic of Bashkortostan, it advantageous to look at the background of other regions PFD due to the maximum value of the index, as the ratio of the area of the region to the area of the Russian Federation.

\section{Conclusions}

After we calculated all the partial potentials, there was found total investment potential of each of the studied regions. To this there were added together all the partial potentials. The results are shown in Table 8.

Table 8. Total potential of subjects for 2007-2011, the PFD.

\begin{tabular}{|c|c|c|c|c|c|}
\hline Year & Rep. Of Bashkortostan & Rep. Od Mari El & Nizhniy Novgorod region & Samara Region & Rep. of Tatarstan \\
\hline 2007 & 279,45 & 139,4 & 305,75 & 306,1 & 308,35 \\
\hline 2008 & 305 & 156,85 & 270,55 & 325,5 & 319,8 \\
\hline 2009 & 279,8 & 155,4 & 269,1 & 308,68 & 324,3 \\
\hline 2010 & 275,55 & 157,1 & 283,55 & 304,4 & 310,45 \\
\hline 2011 & 290,45 & 160,95 & 293,9 & 282,2 & 315,1 \\
\hline
\end{tabular}

Thus, analyzing the aggregated data for the total investment potential of subjects of PFD analyzed time period, it can be noted that the stable leader despite internal variability in this case is the Republic of Tatarstan. of Russia.

Declines in 2009-2010 can be explained by the global financial crisis that had a significant impact on the economy

In order to improve the investment potential of the regions, it is necessary to develop an effective investment policy at the regional level, which key principles should be next:

- creating conditions for effective functioning of the market for goods, services and capital on the basis of equal competitive regime for entrepreneurs and investors;

- Development and implementation of a favorable regulatory legal regime of economic activities of domestic and foreign investors, ensuring the stability of the economic environment for investment;

- Openness pursued region's investment policy; ensuring clarity and transparency of the investment process available to all investors the information required for the implementation of investment activities;

- The balance of public, social, political and economic interests of all participants in the investment and financial markets;

- Mutual responsibility and fulfillment of undertaken in accordance with the law of obligations by both the executive branch and the other participants of the investment process;

- development a positive image of the region, which will increase capital investment from both domestic and from foreign investors.

\section{References}

Casi L., Resmini L. Spatial complexity and interactions in the FDI attractiveness of regions // Papers in Regional Science

Torrecillas, C. , Fischer, B.B. How attractive are innovation systems for knowledge intensive services' FDI? a regional perspective for Spain//Journal of Technology Management and Innovation.- Volume 6, Issue 4, 2011, Pages 45-59

Gallyamova D. Kh. Development of Globalization in the Modern Economy // World Applied Sciences Journal 30 (9): 1160-1165, 2014 
Kandogan Y. Regional foreign direct investment potential of the states within the US//Journal of Economics and Business.-2012.Vol.64,Issue4.-pp.306-322

Bagautdinova, N., Gafurov, I., Kalenskaya, N., Novenkova, A. The regional development strategy based on territorial marketing (The Case of Russia)// World Applied Sciences Journal.- Volume 18, Issue SPL.ISSUE. 18, 2012, Pages 179-184

Brehova, J., Yakovenko, V. Management of the investment process at the regional level (on the sample of the Volgograd Region of Russia)// World Applied Sciences Journal.- Volume 27, Issue 6, 2013, Pages 796-802

Ajupov A.A., Artamonov A.B., Kurilov K.U., Kurilova A.A. Economic bases of formation and development of financial engineering in financial innovation // Mediterranean Journal of Social Sciences vol. 5 № 24, November 2014, pp. 148-153.

Kinossian, N. (2006). Urban redevelopment programmes in Kazan, Russia. Contributions to Economics, pp. 319-336.

Cristofari, C. , Storai, C., Canaletti, J.L. Development policy to increase the competitiveness of renewable energy-sector companies in a territory like Corsica (France)// Renewable and Sustainable Energy Reviews.- Volume 32, April 2014, Pages 61-66

Glebova, I., Khabibrakhmanova, R., Yasnitskaya, Y. The analysis of the impact of the investment attractiveness factors of the region on the fixed capital investments in the economy of the Republic of Tatarstan//Middle East Journal of Scientific Research.- Volume 17, Issue 10, 2013, Pages 1498-1502

Gadzhiev, Y.A., Akopov, V.I., Krestovskikh, T.S. Economy of Russia's Northern regions: Investment in fixed assets//Studies on Russian Economic Development.- Volume 23, Issue 5, September 2012, Pages 488-498

Bagautdinova N.G., Gafurov I.R., Novenkova A.Z. The transformation of region's economic area governed by the development of industrial region//World Applied Sciences Journal.- Volume 25, Issue 7, 2013, Pages 1113-1117

Kurmangaliyeva, A. Factors determining investment attractiveness of the regions of Kazakhstan under conditions of the national economic policy//Actual Problems of Economics.- Volume 140, Issue 2 PART 2, 2013, Pages 31-38

Gallyamova, D Cluster policy as a tool of regional economics competitiveness improvement. Economic Annals-XXI, Volume 3-4, Issue 1, 2014, Pages 12-15.

Ajupov A.A., Mishina M.S., Ivanov M.E. Method of valuation of financial factors influencing the implementation of liquidity risk for leasing companies // Mediterranean Journal of Social Sciences vol. 5 № 24, November 2014, pp. 154-159

Garanti, Z. Geographic concentration of economic activities in Latvia//Middle East Journal of Scientific Research.- Volume 17, Issue 2, 2013, Pages 213-218 